\title{
Performance Analysis of Non Burn Cooking Device Using Commercial Grade Quicklime as Heating Fuel
}

\author{
Niswan Dhakal ', Bhakta Bahadur Ale', Nawraj Bhattarai \\ Department of Mechanical Engineering, Pulchowk Campus, Institute of Engineering, Tribhuvan University, Kathmandu, Nepal \\ Corresponding Email: "niswandhakal@ioe.edu.np
}

\begin{abstract}
The need for portability and easy to handle devices has been felt by the trekkers and campers. In a country like Nepal, with tough geographical terrain and changing climates, a non burn cooking alternative is sought for outdoor cooking. Quicklime or Calcium Oxide ( $\mathrm{CaO}$ ) is commercially available in abundance. $\mathrm{CaO}$ releases $64 \mathrm{~kJ}$ of heat during slaking at Normal temperature and Pressure. Boiling of water, preparing tea, boiling egg, preparing omelet and preparing instant noodles were tested with an average of $32.7 \%$ deviation from theoretical values without considering the manufacturing specification of $90 \%$ purity. Calculating with the manufacturing specification, the error reduced to $27.3 \%$. Though cooking is correlated to the subjective preference of individuals, the highest cooking temperature was recorded 86.5 ${ }^{\circ} \mathrm{C}$ (boiling water), and the highest temperature of inner pot reached was $121.1{ }^{\circ} \mathrm{C}$ in that case. The highest temperature reached in each of cooking purposes were respectively as; boiling egg on water $\left(75.6^{\circ} \mathrm{C}\right)$, boiling egg without using water $\left(11.2^{\circ} \mathrm{C}\right)$, preparing tea $\left(85.9^{\circ} \mathrm{C}\right)$ and preparing instant noodles $\left(68.3^{\circ} \mathrm{C}\right)$. The quantity of cooing material resulted in higher efficiencies as evident by the factor that minimum deviation from theoretical calculation was seen during the cooking of noodles $(17.5 \%)$ and the maximum deviation was observed during preparation of boiled egg without using water or secondary pot $(58.5 \%)$. The device was not found financially feasible for household cooking and for cases where transportation cost incurred is high; the device was financially feasible (Rs. 14 as compared to above Rs. 400 and Rs. 250 of LPG based and kerosene based cooking respectively).
\end{abstract}

\section{INTRODUCTION}

$\mathrm{O}$ $\mathrm{N}$ usage basis, apart from household the portability of the cooking stove and high energy density of the heating fuel is of importance in country like Nepal, where tourism is a huge asset and the geographical topography dictates the mode of development [1], [2]. Having a varying and inconsistent weather pattern is of another concern [3], [4]. The major source of fuel for cooking, firewood is not highly abundant in the rocky terrains and is not suitable for high altitude trekkers and causes various environmental effects [5]. LPG gas cylinders are non portable means for trekkers and campers alike. The probability of forest fire is enhanced while camping in the forests during windy seasons [5]. An economic, portable, green heating device is sought for aforementioned purposes. High heat generation during slaking of quicklime was selected to be a viable option to investigate for heating purposes.

Quicklime or Calcium Oxide $(\mathrm{CaO})$ is a compound formed by the combination of identical ratio of Oxygen and Calcium by moles. One of the major properties of $\mathrm{CaO}$ is that it provides high heat when added to water [6]. The high heat generating $\mathrm{CaO}$ is locally available in different forms in market (viz. for house painting, for edible purpose as used in betel leaf). The main objective of the research is to use locally available materials to develop an economic, green and portable cooking/heating device and investigate its performance for different cooking purposes.

\section{METHODOLOGY}

\section{A. Sample Collection}

Calcium Oxide was found commercially in different forms and varied in properties and purity [7]. Based on the usage there were two types of commercial grade quicklime available. Since $\mathrm{CaO}$ readily reacts with air to form calcium Carbonate, the loose storage of sample A and only the manufacturing lot of Nov/Dec was available hence was disregarded. Thenceforth sample B was considered for experimentation.

TABLE 1

Types of quicklime commercially available Kathmandu with specifications

\begin{tabular}{|c|c|c|}
\hline Specifications & Sample A & Sample B \\
\hline Manufacturer & Rajasthan Lime & $\begin{array}{l}\text { Sahil Lime Industries, } \\
\text { Jharkhand Bihar }\end{array}$ \\
\hline Type & Dolomite Lime & Regular Lime \\
\hline $\begin{array}{l}\text { Manufacturer Cost, } \\
\text { NPR } / \mathrm{kg}\end{array}$ & 14 & 8 \\
\hline $\begin{array}{l}\text { Retail Price, } \\
\text { NPR/kg }\end{array}$ & 30 & 100 \\
\hline Composition & $\begin{array}{l}\mathrm{CaO}:>53 \% \text {; } \mathrm{MgO}: \\
>33 \% \\
\mathrm{SiO}_{2}: 3-4 \% \text {; Others: } \\
<10 \%\end{array}$ & $\begin{array}{l}\mathrm{CaO}: 90 \% ; \text { Mgo : } 3 \% \\
\mathrm{SiO}_{2}=3 \% ; \text { Others: } 4 \%\end{array}$ \\
\hline Storage & $\begin{array}{l}\text { Loose plastic bags, } \\
\text { easily contaminated with } \\
\text { air }\end{array}$ & $\begin{array}{l}\text { Hand Packed air sealed } \\
\text { plastic bags }\end{array}$ \\
\hline
\end{tabular}

Thus the Sample B was considered for further experiments. The samples were further subjected to water heating tests for selections for experiments for different cooking purposes. The availability of the sample A also proved a determining factor in the selection of the samples.

\section{B. Experimental Setup}

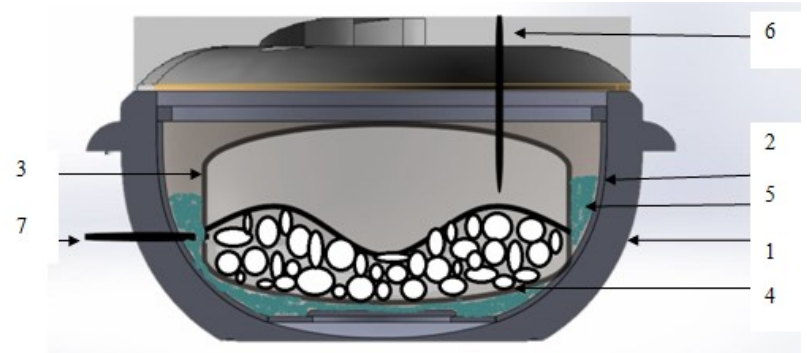

Fig.1. Experimental setup 
Commercial hot-case box was taken for experimentation as shown in Fig.1. since it provided the required thermal insulation and could contain the inner pot as described in later section. The secondary/cooking pot was kept inside the primary pot. Holes were made in the pots for insertion of the thermometers for measuring the temperature inside the primary pot and secondary pot.

Here the outer pot or the primary pot (1) encloses the secondary pot (3) and the mixture of heating fuel (5) or quick lime and water. The primary pot has outer epoxy resin insulation (2) with the inner pot made of Stainless steel. The secondary pot encloses the cooking material (4). The inner temperature of the pot is measured using thermometer (7) and the temperature of the cooking material is measured using thermometer (6).

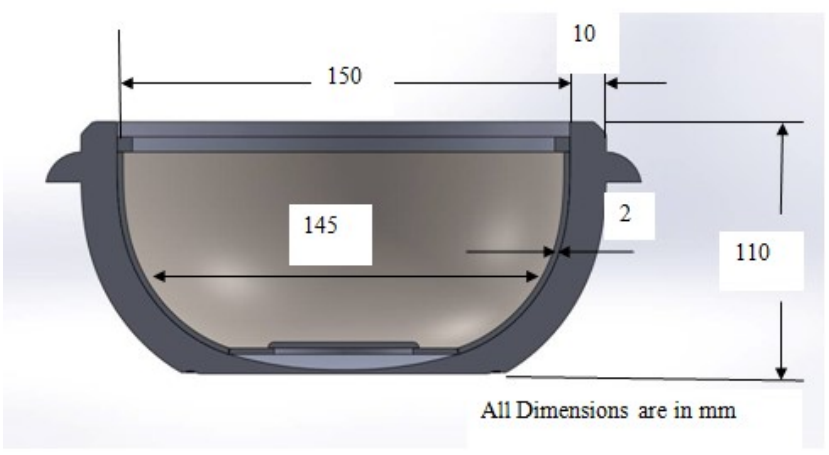

Fig.2. Cross sectional front view of the primary pot

The Cross sectional front view of the primary pot with its dimension is shown in Fig. 2.

\section{RESULT AND DISCUSSIONS}

\section{A. Calculations of Heat}

The process of addition of water to $\mathrm{CaO}$ to form Calcium Hydroxide $\left(\mathrm{Ca}(\mathrm{OH})_{2}\right)$ is called slaking of lime. Calcium Hydroxide is also known as slaked lime in common terms and generates huge amount of heat during slaking [6]. The fundamental equation per mol of slaking of lime is:

$$
\mathrm{CaO}+\mathrm{H}_{2} \mathrm{O} \leftrightarrow \mathrm{Ca}(\mathrm{OH})_{2}+64 \mathrm{~kJ}_{298 \mathrm{~K}}
$$

The heat of reaction is calculated as:

$$
\Delta \mathrm{H}_{\mathrm{f}} \mathrm{CaO}+\Delta \mathrm{H}_{\mathrm{f}} \mathrm{H}_{2} \mathrm{O}=\Delta \mathrm{H}_{\mathrm{f}} \mathrm{Ca}(\mathrm{OH})_{2}+\Delta \mathrm{H}_{\mathrm{r}}(2)
$$

Where,

$$
\begin{aligned}
& \Delta \mathrm{H}_{\mathrm{f}} \mathrm{CaO}=\text { Heat of formation of } \mathrm{CaO}=-635 \mathrm{~kJ} / \mathrm{mol} \\
& \Delta \mathrm{H}_{\mathrm{f}} \mathrm{H}_{2} \mathrm{O}=\text { Heat of formation of Water }=-286 \mathrm{~kJ} / \mathrm{mol} \\
& \Delta \mathrm{H}_{\mathrm{f}} \mathrm{Ca}(\mathrm{OH})_{2}=\text { Heat of formation of } \mathrm{Ca}(\mathrm{OH})_{2}=-985 \mathrm{~kJ} / \mathrm{mol} \\
& \Delta \mathrm{H}_{\mathrm{r}}=\text { Heat of reaction of slaking of lime }=-64 \mathrm{kj} / \mathrm{mol} \\
& \text { Here negative sign indicates the reaction is exothermic. [8] } \\
& \text { The equation can be expressed in simpler form as: }
\end{aligned}
$$$$
56 \mathrm{~g}(\mathrm{CaO})+18 \mathrm{~g}\left(\mathrm{H}_{2} \mathrm{O}\right)=74 \mathrm{~g}\left(\mathrm{Ca}(\mathrm{OH})_{2}+64 \mathrm{~kJ}[6]\right. \text {, [9] }
$$

Therefore, 56 units of quicklime and 18 units of water combine to give 74 units of slaked lime. The ratio of hydroxide to $\mathrm{CaO}$ is $74 \div 56=1.32: 1$. This means that $1 \mathrm{Kg}$ of $\mathrm{CaO}$ and $0.32 \mathrm{Kg}$ of water will produce $1.32 \mathrm{Kg}$ of $\mathrm{Ca}(\mathrm{OH})_{2}$, this is the minimum amount of water required for chemical reaction, so calcium hydroxide contains $75.7 \%$ $\mathrm{CaO}$ and $24.3 \% \mathrm{H}_{2} \mathrm{O}$. The process of adding water to calcium oxide to produce calcium hydroxide is referred to as hydration process or lime slaking. The hydration of $\mathrm{CaO}$, commercially referred to as quick lime, is an exothermic process releasing a great quantity of heat.

The consumption of heat was modeled in an excel sheet to calculate the final values. For instance the $64000 \mathrm{~J}$ of heat is produced when reacting $1 \mathrm{~mol}(56 \mathrm{~g})$ of $\mathrm{CaO}$ with $1 \mathrm{~mol}$ water $\left(18 \mathrm{~g} \mathrm{H}_{2} \mathrm{O}\right)$. During the reaction ideally when no vessels is used, the heat is used to raise the temperature of $\mathrm{Ca}(\mathrm{OH}) 2$, the product of the reaction.

Thus the temperature attained ideally on Normal condition of temperature $\left(25^{\circ} \mathrm{C}\right)$ and pressure (1atm) is calculated as

Heat evolved $=\left(\mathrm{m}_{\mathrm{c}}+\mathrm{m}_{\mathrm{w}}\right) \times\left(\mathrm{c}_{\mathrm{c}}\right) \times\left(\mathrm{t}_{\mathrm{f}}-\mathrm{t}_{\mathrm{o}}\right)$

Where,

$$
\begin{aligned}
& \mathrm{m}_{\mathrm{w}}=\text { mass of water as reagent, } \mathrm{kg} ; \\
& \mathrm{m}_{\mathrm{c}}=\text { mass of quick lime, } \mathrm{kg} \\
& \mathrm{c}_{\mathrm{c}}=\text { sp. heat capacity of } \mathrm{Ca}(\mathrm{OH})_{2}, \mathrm{~J} / \mathrm{kg} /{ }^{\circ} \mathrm{C}=1182 \mathrm{~J} / \mathrm{kg} /{ }^{\circ} \mathrm{C} \\
& \mathrm{t}_{\mathrm{f}}=\text { final temperature, }{ }^{\circ} \mathrm{C} ; \mathrm{t}_{0}=\text { ambient temperature, }{ }^{\circ} \mathrm{C}
\end{aligned}
$$

The highest temperature thus attained was $756.7^{\circ} \mathrm{C}$.

For experimental purposes the heat consumed by steel pots and the heat consumed by cooking materials were also considered so the above equation became,

$$
\begin{aligned}
& \text { Heat evolved }=\left[\left\{\left(\mathrm{m}_{\mathrm{c}}+\mathrm{m}_{\mathrm{w}}\right) \times\left(\mathrm{c}_{\mathrm{c}}\right)+\mathrm{m}_{\mathrm{s}} \times \mathrm{c}_{\mathrm{s}}+\right.\right. \\
& \left.\left.\mathrm{m}_{\mathrm{i}} \times \mathrm{c}_{\mathrm{i}}\right\} \times\left(\mathrm{t}_{\mathrm{f}}-\mathrm{t}_{\mathrm{o}}\right)\right]
\end{aligned}
$$

Where,

$$
\begin{aligned}
& \mathrm{m}_{\mathrm{s}}=\text { total mass of steel pots, } \mathrm{kg}=.247 \times 10^{3} \mathrm{~kg} \\
& \mathrm{c}_{\mathrm{s}}=\text { specific heat capacity of steel pots }=502 \mathrm{~J} / \mathrm{kg} / \mathrm{K} \\
& \mathrm{m}_{\mathrm{i}}=\text { mass of inner contents or cooking materials, } \mathrm{kg} \\
& \mathrm{c}_{\mathrm{i}}=\text { specific heat capacity of cooking materials, } \mathrm{J} / \mathrm{kg} /{ }^{\circ} \mathrm{C}
\end{aligned}
$$

The error was calculated for the highest temperature attained,

$$
\text { \%error }=\frac{\text { theoretical val } \quad \text {-experimental value }}{\text { theoretical value }} \times 100 \%
$$

Each experiment was conducted in three sets and the average of the three was taken into consideration for the experiment and analysis. [10]

The thermal efficiency was calculated as

$$
\begin{aligned}
& \text { Thermal efficiency, } \%= \\
& \frac{\text { total Heat recieved by } t \square \text { e cooking materials }}{\text { Total Heat produced by used CaO }} \times 100 \%
\end{aligned}
$$

The average of thermal efficiencies of each cooking purposes was calculated to be $38.09 \%$ 


\section{A. Preliminary Test Results}

Preliminary tests were conducted without experimental data so as to observe the performance of slaking of Quicklime, various observations were made as follows to yield effective results: i) The granules of $\mathrm{CaO}$ were finely crushed. ii) For uniform dissipation of water or for uniform slaking, $\mathrm{CaO}$ powders were kept in small packets of 10 grams each. iii) The leakage through external pot was minimized using additional epoxy resin at the holes made for temperature measurement. iv) The fine granules of $\mathrm{CaO}$ in packets were wrapped around the secondary pot for uniform heating. v) Cooking and heating performances were tested and evaluated for various cooking purposes. vi) $100 \mathrm{ml}$ of water was used for boiling purposes to maintain uniformity in comparisons.

\section{B. Slaking of $30 \mathrm{~g}$ Quicklime}

The highest temperature attained was $82.6{ }^{\circ} \mathrm{C}$ at the inside of the primary pot and $58.8^{\circ} \mathrm{C}$ at the cooking material with the error of $29.2 \%$. The result obtained was compared as below:

TABLE 2

Comparison of the slaking of $30 \mathrm{~g}$ of quicklime of sample A and sample B

\begin{tabular}{lccc}
\hline \hline \multicolumn{1}{c}{ Specifications } & $\begin{array}{c}\text { Sample } \\
\mathbf{A}\end{array}$ & $\begin{array}{c}\text { Sample } \\
\mathbf{B}\end{array}$ & $\begin{array}{c}\text { Theoretical } \\
\text { value }\end{array}$ \\
\hline Highest temp. attained, ${ }^{\circ} \mathrm{C}$ & 58.8 & 40.8 & 83 \\
Max. rise in temperature, ${ }^{\circ} \mathrm{C}$ & 34.1 & 15.9 & 58 \\
error, $\%$ & 29.2 & 50.9 & $0 \%$ \\
Weight of $\mathrm{CaO}, \mathrm{g}$ & 30 & 30 & 30 \\
Weight of water to boil, g & 100 & 100 & 100 \\
Ambient temperature, ${ }^{\circ} \mathrm{C}$ & 25 & 25.2 & 25 \\
\hline \hline
\end{tabular}

The significant difference in the error \% was crucial for the selection of the sample for further experiments. The maximum temperature of water attained was not the desired one and various weight of the sample $\mathrm{C}$ was taken to account for the performance analysis and decide the feasibility for the cooking purposes. Three samples each of sample B were taken each of 30,50 and $60 \mathrm{~g}$ for slaking/heating material. Water used was $1 / 3$ rd of the amount approximately and following results were obtained.

\section{Effect of Weight of Quicklime in the Heating Process.}

As identified from the literature, the temperature attained is directly proportional to the heat gained, thus the variation of highest temperature attained or the maximum temperature rise was plotted against the quantity of quick lime used for slaking and following results were obtained.

From the experiments it was observed that the temperature of water in the vessel reached as high as $87.5{ }^{\circ} \mathrm{C}$ and the temperature above $80{ }^{\circ} \mathrm{C}$ was retained for more than 15 minutes so the $60 \mathrm{~g}$ of sample $\mathrm{B}$ was selected for further experimentation.

The higher error $\%$ in the later samples could be due to the contamination with air. As $\mathrm{CaO}$ readily reacts with carbon dioxide in air to form calcium carbonate, the later experiments with the opened packets of Calcium oxide gave higher error \%. Accounting for the earlier error of 30\% with earlier samples, further sample tests with $60 \mathrm{~g}$ Calcium Oxide was selected for further experimentation. The observed parameters were carefully noted and thus used for the test of various cooking purposes.

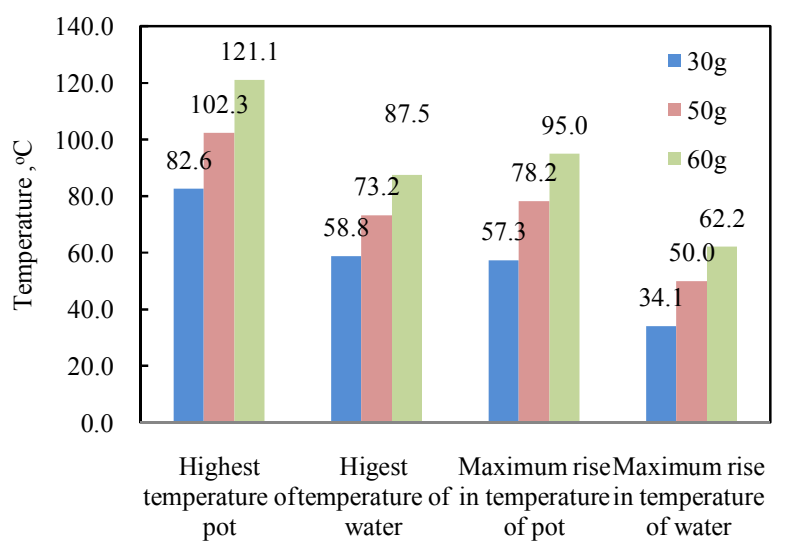

Fig.2. Performance of slaking of quicklime by weight

\section{Heating Water}

It is seen from the graph that there was a sudden rise in temperature of the primary pot however as the heat transferred to the inner content or food material, a material with higher specific heat capacity the rate of reaction slowed down and did not reach the temperature it would have expected to reach (i.e. $756.7^{\circ} \mathrm{C}$ ). It was also evident that the steady rise in temperature of the inner pot was due to uniform heating as the packets of quicklime were uniformly covering the secondary pot. Also high specific heat capacity prevented the abrupt rise in temperature of the inner pot. After 15 minutes the primary pot attained its maximum temperature $\left(121.1^{\circ} \mathrm{C}\right)$, and the inner pot attained its maximum temperature in 22 minutes $\left(87.5^{\circ} \mathrm{C}\right)$

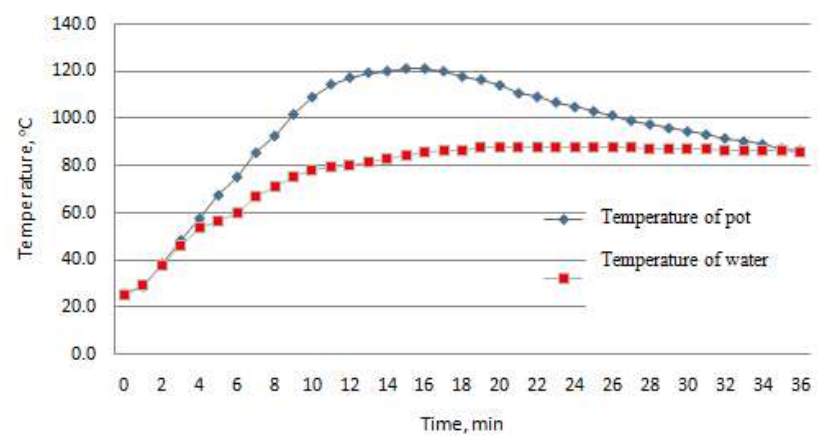

Fig.3. Temperature profile while boiling water and slaking of $60 \mathrm{~g}$ lime

However, the difference in temperature was evident in primary and secondary pots. The error from the theoretically calculated value was $33 \%$. The high error $\%$ could be due to the air leakage from the putty material used to seal the leakage. 
Despite the high error $\%$, the water was able to be heated to $87.5^{\circ} \mathrm{C}$ which was on par with the desired output.

\section{E. Preparation of Black Tea}

Firstly the accepted parameter of $100 \mathrm{ml}$ of black tea (water) and $60 \mathrm{~g}$ of $\mathrm{CaO}$ was used for the test and upon subsequent findings the parameters could be retested and adjusted. The results as shown in figure were obtained while preparing black tea:

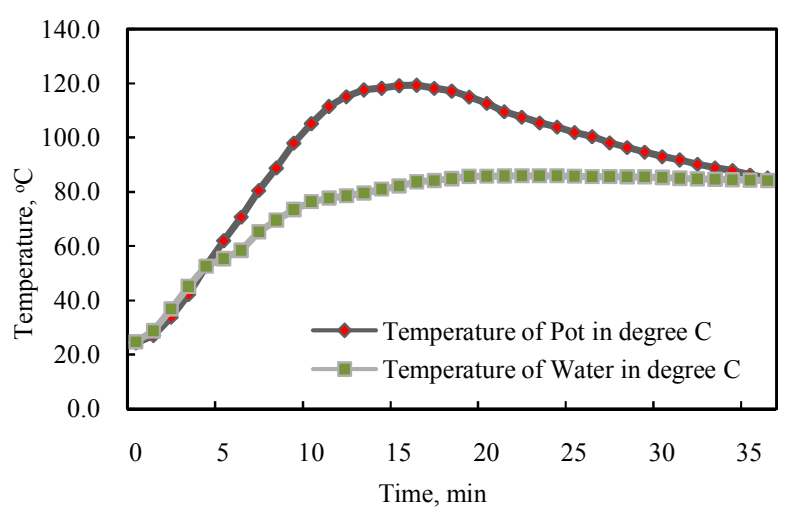

Fig. 1. Temperature profile during preparation of $100 \mathrm{ml}$ black tea using

$$
60 \mathrm{~g} \mathrm{CaO}
$$

It was observed that the temperature attained was well within the acceptable range of making tea. However, due to sustained high temperature, the black tea got overcooked and tasted bitter. Thus the alternative combination of cooking parameters was desired. The specific heat capacity of black tea was taken to be $4200 \mathrm{~J} / \mathrm{kg} /{ }^{\circ} \mathrm{C}$ which is slightly lower than the actual value ( the actual value was not found in literature so small quantity of black tea was considered not to make significant difference in the desired output), The error $\%$ was calculated to be $34.6 \%$. The error $\%$ was found to be slightly higher $(0.6 \%)$ than the one obtained for pure water and this could be due to the effect of addition of black tea material and its specific heat being not taken into account.

Due to being overcooked the test was made for $30 \mathrm{~g} \mathrm{CaO}$ and food being a preference of an individual preference test of taste was done along with the plotting of temperature profile

The result on preparing black tea with slaking of $30 \mathrm{~g} \mathrm{CaO}$ did not provide with affirmative results. It was contrary to the use of $60 \mathrm{~g} \mathrm{CaO}$ used for heating. The desired temperature was not reached and hence the black tea was undercooked.

Hence for the purpose of determining different parameters, quantity of water in the secondary pot was increased and following results were obtained.

There was a considerable rise in temperature due to the addition of $\mathrm{CaO}$ for slaking. However the addition of water in secondary pot caused a rise in temperature as compare to the temperature profile based on slaking of $30 \mathrm{~g} \mathrm{CaO}$. It was also noted that the temperature of the Black tea was retained for higher amount of time. The black tea was prepared for drinking and it received general feedback.

As evident from the table, black tea was reached highest temperature in 13 min when the heating material used was $30 \mathrm{~g}$ but the heat retained and preferred taste was when $60 \mathrm{~g}$ of $\mathrm{CaO}$ was used as heating material and the use better efficiency when more cooking material was used was due to the reason of leakage of air through the holes made for taking the temperature, more the cooking material, less the air heat loss due to leakage.

TABLE 2

Comparison of cooking of black tea for various quantities of cooking material and $\mathrm{CaO}$

\begin{tabular}{ccccccc}
\hline \hline CaO, & $\begin{array}{c}\text { Black } \\
\text { Tea, } \\
\mathbf{m l}\end{array}$ & $\begin{array}{c}\text { error, } \\
\%\end{array}$ & $\begin{array}{c}\text { Time } \\
\text { to } \\
\text { heat, } \\
\text { min }\end{array}$ & $\begin{array}{c}\text { Time } \\
\text { temp. } \\
\text { above } \\
\mathbf{6 5 0 C} \text { is } \\
\text { retained, } \\
\text { min }\end{array}$ & $\begin{array}{c}\text { max. } \\
\text { temp., } \\
{ }^{\mathbf{0}} \mathbf{C}\end{array}$ & Remarks \\
\hline 30 & 100 & 36.05 & 13 & 0 & 61.6 & undercooked \\
60 & 100 & 35.1 & 22 & $>30$ & 86 & overcooked, \\
60 & 200 & 26.4 & 24 & 22 & 67.2 & Preferred \\
\hline \hline
\end{tabular}

F. Cooking Noodles

The next test included the cooking of noodles. The instant noodles with net weight $38 \mathrm{~g}$ was used as test sample. Noodles was kept in secondary pot for cooking.

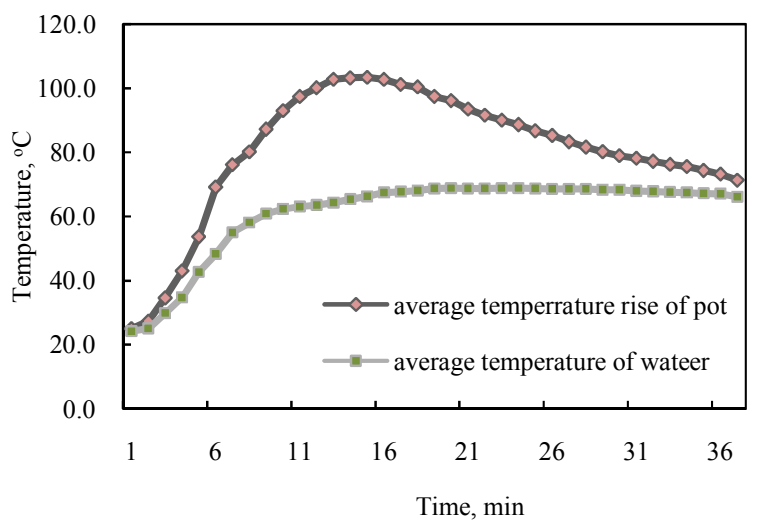

Fig. 2. Temperature profile while cooking noodles using $\mathrm{CaO}$

It was observed as in Figure6, all the water inside the secondary pot dried up or got absorbed by the instant noodles. The soup of the noodles could not be prepared. However, the prepared noodles gravy of the one was eatable and well cooked. , The error \% during this experiment was calculated to be $17.5 \%$. The reason might be the use specific heat capacity of a specific type of wheat as the specific heat capacity of whole noodles which might in fact be significantly lower than the assumed value. First there was a steady rise in temperature of both the pots. The temperature of the primary pot reached the maximum value first and then followed by the decrease in temperature of the primary pot. The temperature of secondary pot continued rising and after reaching its maximum value both the temperatures started falling at slower rate. 


\section{G. Preparing Boiled Egg}

Firstly the experiment was conducted on the egg being kept on water of $100 \mathrm{ml}$ and the weight of $\mathrm{CaO}$ being $60 \mathrm{~g}$ as our earlier experiments suggested. The Weight of egg was $49 \mathrm{~g}$. Many samples of eggs were collected and same weight was preferred for experiments. Following results were obtained

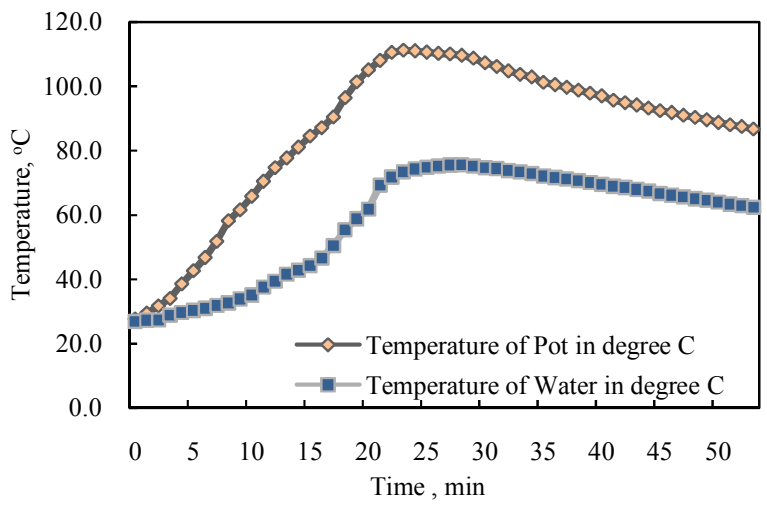

Fig. 3. Temperature rise during boiling egg at $100 \mathrm{ml}$ water and $60 \mathrm{~g} \mathrm{CaO}$

It was observed as in Fig.7, that the temperature inside the secondary pot rose to $75^{\circ} \mathrm{C}$ in about 26 minutes and retained for three minutes more. Theoretically this was an ideal time and temperature for setting of the albumen. However the resultant egg was not hard boiled but a soft boiled one. Hence boiling of egg was tried without using water and keeping both $\mathrm{CaO}$ and egg in primary pot. The error during the experiment was calculated to be $13 \%$.

It was observed that the hardboiled egg was also obtained without boiling water by removing the secondary pot. This in fact saved some heat. The heat required to heat the water was also used in the boiling of egg. Though the term boiling is used no water was used for setting the egg parts in this experiment. It was also observed that $30 \mathrm{~g}$ of $\mathrm{CaO}$ was sufficient for cooking egg inside the shell. However there had also been a significant leakage when the temperature rose as high. The error in this case rose to as high as $62 \%$. It can be seen that the high error \% was significantly due to the leakage of air. The comparison of the two methods for boiling egg was as follows:

TABLE 3

Comparison of different processes for preparing boiled egg

\begin{tabular}{lcc}
\hline \hline \multicolumn{1}{c}{ Parameters } & $\begin{array}{c}\text { without using } \\
\text { secondary pot }\end{array}$ & $\begin{array}{c}\text { Boiling egg in } \\
\text { water }\end{array}$ \\
\hline Weight of CaO,g & 30 & 60 \\
Volume of water, ml & 0 & 100 \\
$\begin{array}{l}\text { Highest temperature } \\
\text { attained, }{ }^{\circ} \mathrm{C}\end{array}$ & 112.5 & 75.6 \\
$\begin{array}{l}\text { Error } \\
\text { Remarks }\end{array}$ & $19 \%$ & $62 \%$ \\
\hline \hline
\end{tabular}

The tradeoff was between the efficiency and the temperature raised, At the cost of efficiency, desired output was reached with less expense. However the efficiency could be increased or the error could be reduced by sealing the primary pot tight from leakage. Again the result was the question of preferences.

\section{H. Heating Water at Cold Temperature}

The next experiment was conducted inside a refrigerator with ambient temperature inside the refrigerator being -13.2 ${ }^{\circ} \mathrm{C}$. Since no regular temperature profile was able to be generated, the time required to heat the ice cubes adding ice cubes at ambient temperature inside the cooking pot, was lengthened. The temperature after 30 minutes was found to be $39.8{ }^{\circ} \mathrm{C}$ in an average. This suggested the possibility of use of this device for drinking purpose and purpose of heating water at cold climates, especially mountaineering.

\section{Summary of the Results}

Table 5 shows that the low efficiencies of below $20 \%$ and higher deviation from error above $60 \%$ occurred when the cooking was performed under dry conditions. Preparation of egg without using secondary pot and preparation of omelet could not retain heat. The results deviated $25-35 \%$ from the theoretical values with an average error of $32.73 \%$. The performance analysis of the cooking stove for different cooking purposes are summarized in the table below:

TABLE 4

Summary of performance analysis for different cooking purposes

\begin{tabular}{lccccc}
\hline \hline \multicolumn{1}{c}{ Purposes } & $\begin{array}{c}\text { Wt of } \\
\text { CaO, g }\end{array}$ & $\begin{array}{c}\text { Ambient } \\
\text { temp, }{ }^{\circ} \mathbf{C}\end{array}$ & $\begin{array}{c}\text { Max. } \\
\text { temp }\end{array}$ & $\begin{array}{c}\text { error, } \\
\mathbf{\%}\end{array}$ & $\begin{array}{c}\text { efficiency } \\
\mathbf{\%}\end{array}$ \\
\hline Sample B 30g & 30 & 24 & 58.8 & 28.3 & 41.7 \\
Sample B 50g & 50 & 25 & 73.2 & 37.3 & 36.7 \\
Sample B 60g & 60 & 25 & 87.5 & 33.9 & 38.1 \\
Black tea & 30 & 24.3 & 61.6 & 25.1 & 45.4 \\
Black tea 100 ml & 60 & 24 & 86 & 34.6 & 36.3 \\
Black tea 200 ml & 60 & 26.5 & 67.2 & 26.4 & 48.5 \\
Noodles & 60 & 24.8 & 68.8 & 12.7 & 41.0 \\
Eggs (sp. Heat 1.67) & 60 & 27 & 75.6 & 13.2 & 35.6 \\
Eggs (sp. Heat 1.67) & 30 & 25.2 & 112.5 & 62.3 & 19.2 \\
Omelet & 30 & 25.5 & 55.3 & 64.7 & 7.9 \\
Soup & 60 & 26.2 & 70.8 & 21.1 & 32.5 \\
Macaroni & 60 & 24.7 & 62.6 & 17.5 & 39.1 \\
\hline \hline
\end{tabular}

Presence of water in cooking device helped to retain heat and there was less deviation. As compared to the two cooking purposes performed under dry conditions (viz. boiling egg secondary pot and preparing omelet), the error was $65 \%$ and $62 \%$, respectively. The efficiencies in these cases were significantly lower $8 \%$ and $19 \%$ respectively. The device was successfully used in preparing black tea, preparing noodles, boiling egg and preparing omelet. Whatsoever the desired temperature was attained in both cases. The average overall efficiency was 38.09\% (39.64\% for dry conditions). The average deviation from highest temperature attained was $32.73 \%$ and on dry conditions it was $23.9 \%$. Hence the cooking apparatus or the cooking stove was more efficient while using to cook food with high specific heat capacities. Moreover higher heat was retained when more cooking material was used. 


\section{FINANCIAL ANALYSIS}

The comparison was made with the calculation of costs for different cooking purposes as performed in the experiment. To cook anything Assuming lossless system and 10\% evaporation of water we have

$$
\mathrm{Q}_{\mathrm{t}}=\mathrm{Q}_{1}+\mathrm{Q}_{2}
$$

Where,

$\mathrm{Q}_{1}$ - heat required to heat inner contents from $\mathrm{T}_{1}$ to $\mathrm{T}_{2}$ $\mathrm{Q}_{2}$-heat required to evaporate $10 \%$ of total mass of water

$\mathrm{Q}_{1}=\left(\mathrm{C}_{\mathrm{p} 1} \mathrm{~m}_{1+} \mathrm{C}_{\mathrm{p} 2} \mathrm{~m}_{2}\right)\left(\mathrm{T}_{2}-\mathrm{T}_{1}\right)$

$\mathrm{Q}_{2}=0.1 \mathrm{C}_{\mathrm{e}} \mathrm{m}_{2}$

$\mathrm{C}_{\mathrm{p} 1}$ - specific heat of inner content $=1.717 \mathrm{~kJ} / \mathrm{Kgk}$

$\mathrm{C}_{\mathrm{p} 2}$ - specific heat of water $=4.180 \mathrm{~kJ} / \mathrm{kgK}$

$\mathrm{Ce}$ - latent heat of evaporation for water $=2,260 \mathrm{~kJ} / \mathrm{kgK}$;

$\mathrm{m}_{1}=1 \mathrm{~kg} ; \mathrm{m}_{2}=1.5 \mathrm{~kg}$

$\mathrm{T}_{1}=25^{\circ} \mathrm{C}$ room temperature;

$\mathrm{T}_{2}=$ as required for different cooking purposes

Hence, total heat/energy required to cook $1 \mathrm{~kg}$ of rice needs around $960.346 \mathrm{~kJ}$ [11]

The financial analysis was performed for three options for cost efficiencies with the cost of fuels in i) Urban areas where the transportation cost is negligible ii) High hills (Chame, Manang) and iii) trekking routes (trans Annapurna Base Camp).

The comparisons were made for specific cooking purposes for individual meal for a day. The reference data taken was as for the boiling water using $60 \mathrm{gm} \mathrm{CaO}$. The comparison was made between the amount and cost required for other types of fuel to raise the temperature to same amount. Here the heat required to initially reach the ignition point for firewood also became significant. For option iii the cooking option was assumed in a way that the transportation cost of cooking stove carried was useful for two meals and was shared by two persons per day. The result looked as follows:

TABLE 5

Comparison of cost for heating $100 \mathrm{ml}$ water using different fuels

\begin{tabular}{lccccc}
\hline \hline $\begin{array}{c}\text { Fuel } \\
\text { type(cooking } \\
\text { methods) }\end{array}$ & $\begin{array}{c}\text { Fuel } \\
\text { consumed, } \\
\text { g }\end{array}$ & $\begin{array}{c}\text { Energy } \\
\text { supplied by } \\
\text { fuel, kJ }\end{array}$ & $\begin{array}{c}\text { Cost I } \\
\text {,Rs }\end{array}$ & $\begin{array}{c}\text { Cost } \\
\text { II } \\
\text { Rs. }\end{array}$ & $\begin{array}{c}\text { Cost } \\
\text { III } \\
\text { Rs. }\end{array}$ \\
\hline Fire wood & 27.3 & 519.8 & 0.27 & 0.77 & 8.42 \\
$\begin{array}{l}\text { LPG based } \\
\text { cooking }\end{array}$ & 1.5 & 69.07 & 0.14 & 0.52 & 400.52 \\
$\begin{array}{l}\text { Kerosene } \\
\text { based cooking }\end{array}$ & 2.5 & 103.6 & 0.30 & 1.34 & 251.34 \\
$\begin{array}{l}\text { Quicklime } \\
\text { based cooking }\end{array}$ & 60.0 & 68.57 & 6.00 & 2.40 & 14.4 \\
\hline \hline
\end{tabular}

It was thus evident from the calculation that the quicklime based cooking is financially feasible only in the cases where the transportation cost incurred is high, as for in trekking and short trips where cooking options is not readily available and one need not carry bulky stoves or fuel storages this method of cooking looks feasible. As seen from above table, the quicklime based cooking for smaller cooking/heating purposes was easier and cheaper. Also it provided the liberty of not having to sit around the cooking stove until the meal was cooked. Though the cooking seemed more expensive than the use of firewood, the use of firewood on extreme weather condition, wind/rain is not feasible.

\section{CONCLUSIONS AND RECOMMENDATIONS}

\section{A. Conclusions}

Commercial grade quick lime was selected for a non burn cooking option as an alternative fuel for cooking. Locally and commercially available materials were taken as test subjects for experiments. It was found that the cooking results are subjective and the amount of cooking time required varied with individual preferences. The results were deviated $25-35 \%$ from the theoretical values with an average error of $32.73 \%$. Each sample test was conducted while slaking of $60 \mathrm{~g}$ quicklime. The highest temperature attained while boiling water was $87.5^{\circ} \mathrm{C}$. The device was successfully used in preparing black tea, preparing noodles, boiling egg and preparing omelet.

The device was small portable handy and was suitable for cooking a single meal for a single person per operation. It cost Rs. 14 as compared to more than Rs. 400 in LPG and and more than Rs. 250 for Kerosene based cooking at places where transportation cost incurred was high. Cost of Firewood based cooking in such cases was Rs. 8.42. However firewood based cooking requires significant setup to prevent from external weather and climate factors.

Presence of water in cooking device helped to retain heat In addition to providing green option for cooking, the device also provided a suitable alternative for cooking in extreme weather (very cold and rainy), heating meals and mainly cooking alternatives during trekking and camping where portability of cooking unit and access of electricity is a concern. However the device was not suitable for use in households as the device cost more expensive as compared to the existing technologies.

\section{B. Recommendations}

Following recommendations are made for further research:

i) Further attempts can be made to increase the thermal efficiency of the cooking apparatus. The quality of quicklime can be protected by proper storage methods.

ii) The cooking apparatus can be scaled for the use in household.

iii) Proper technology can be devised to collect and use the bi-product, slaked lime, which itself has a high commercial value.

iv) The reversibility of the reaction can be investigated within the solar field and the apparatus can be used as a proper energy storage device 


\section{REFERENCES}

[1] CBS, "National Population and Housing Census 2011(National Report)," Gov. Nepal, Natl. Plan. Comm. Secr. Cent. Bu reau Stat., vol. 01, pp. 1-278, 2012.

[2] Ministry of Population and Environment, "Initial National Communication to the Conference of the Parties of the United Nations Framework Convention on Climate Change," p. 181, 2004.

[3] N. MoPE, "Nepal Second National Communication to the conference of parties of the United Nations framework convention on climate change," p. xxii,173, 2014.

[4] MoF, "Economic Survey," 2016.

[5] N. Chettri, E. Sharma, D. C. Deb, and R. C. Sundriyal, "Impact of Firewood Extraction on Tree Structure, Regeneration and Woody Biomass Productivity in a Trekking Corridor of the Sikkim Himalaya," Mt. Res. Dev., vol. 22, no. 2, pp. 150-158, 2002.

[6] V. Slaughter, J and Kerrick, DM and Wall, "Experimental and thermodynamic study of equilibriums in the system calcium oxide--magnesium oxide--silicon dioxide--water--carbon dioxide,” Am. J. Sci.;(United States), vol. 275, no. 2, 1975.

[7] S. Houngaloune, K. S. Ariffin, H. Bin Hussin, K. Watanabe, and V. Nhinxay, "The effects of limestone characteristic, granulation and calcination temperature to the reactivity of quicklime," Malaysian J. Microsc., vol. 6, no. 1, pp. 53-57, 2010.

[8] S. Zumdahl and D. J. DeCoste, Chemical principles. Nelson Education, 2012.

[9] Y. A. Criado, M. Alonso, and J. C. Abanades, "Kinetics of the $\mathrm{CaO} / \mathrm{Ca} \quad(\mathrm{OH}) 2$ hydration/dehydration reaction for thermochemical energy storage applications," Ind. Eng. Chem. Res., vol. 53, no. 32, pp. 12594-12601, 2014.

[10] C. R. Kothari, Research methodology: Methods and techniques. New Age International, 2004.

[11] J. . Shrestha, "Efficiency Measurement of Biogas, Kerosene and LPG Stoves," Biogas Support Progr. Nepal, no. July, p. 12, 2001.

\section{BIOGRAPHIES}

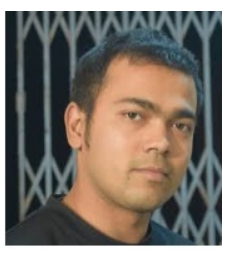

Niswan Dhakal is an interdisciplinary engineer. He received his Bachelor's degree in Mechanical Engineering from Tribhuvan University, Nepal. At present, he is working as a full time lecturer in the Department of Civil Engineering at Nepal Engineering College. He has also worked as a research scholar in Nanyang Technological University, Singapore. He is profoundly involved in Robotics and automation. His research interests lie in the area of Energy Engineering, nanotechnology, bio materials, Robotics etc.

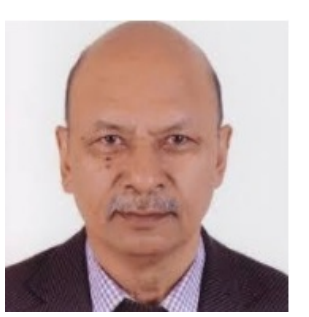

Bhakta Bahadur Ale is a visiting professor and researcher at Center for Energy Studies, Institute of Engineering, Tribhuvan University. $\mathrm{He}$ is a retired professor at the Department of Mechanical Engineering, Pulchowk Campus, Institute of Engineering, Tribhuvan University. $\mathrm{He}$ is a former director of Center for Applied Research and Development at Institute of Engineering, Tribhuvan University. He is a pioneer and leading expert in the area of Thermofluid engineering and automobile in Nepal. He has worked as consultant to many national and international organizations in the area of Renewable Energy Technology and Mechanical Engineering. His research interests lies in the application of Renewable Energy Technologies in developing countries.

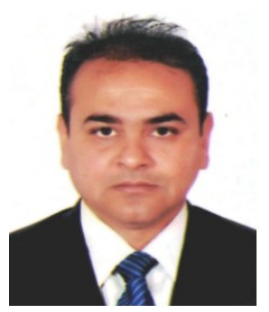

Nawraj Bhattarai is a senior Mechanical Engineer and Energy Engineer. He received his B.E. in Mechanical Engineering degree from Tribhuvan University in 2000. He went on to receive his M.Sc. Renewable Energy Engineering degree from Tribhuvan University in 2004 and his Ph.D. in Energy Planning from Vienna University of Technology, Austria in 2015. At present he is working as an Assistant Professor and Program Coordinator of M.Sc. Engineering in Energy Systems Planning and Management program at the Department of Mechanical Engineering, Pulchowk Campus, Institute of Engineering, Tribhuvan University. He is also an acting director at Center for Energy Studies, Institute of Engineering, Tribhuvan University. He has worked as a research consultant to many organizations. His research interests lie in the area of Renewable Energy Engineering, Solar PV, Micro Hydro technology, Environmental Engineering, Energy Systems Planning, etc. 